\title{
Consortium of five fungal isolates conditioning root growth and arbuscular mycorrhiza in soybean, corn, and sugarcane
}

\author{
CHRISTYAN P. FARIAS, RAFAEL C. DE CARVALHO, FELIPE M.L. RESENDE and LUCAS C.B. AZEVEDO
}

Instituto de Ciências Agrárias, Universidade Federal de Uberlândia, Avenida Amazonas, s/n, Campus Umuarama, 38400-902 Uberlândia, MG, Brazil

Manuscript received on February 17, 2018; accepted for publication on May 21, 2018

\begin{abstract}
Plant growth and arbuscular mycorrhizal colonization were studied in sugarcane, corn and soybean by applying five plant growth promoting fungi: Beauveria bassiana, Metarhizium anisopliae, Pochonia chlamydosporia, Purpureocillium lilacinum, and Trichoderma asperella. Sugarcane, corn and soybean were grown in pots under two treatments: (1) inoculation with the fungal consortium and (2) control without inoculation. In the inoculated treatment, fungal spore suspension were applied to the seeds and shoots were sprayed every 28 days. Means were analyzed by analysis of variance and Tukey's test at 5\% probability level. The experiment was arranged in a completely randomized design, with six replications. Fungi consortium mediate root growth in soybean and corn, and arbuscular mycorrhizal colonization in soybean and sugarcane. These findings are probably caused by the fungi producing phytohormones and inducing the plants to synthesize phytohormones: auxins for root growth; and jasmonic, abscisic, and salicylic acids with a role in the regulation of mycorrhizal colonization. These effects are important when seeking conservation strategies in agriculture and livestock production, since Fungi consortium can better mediate soil resource acquisition, promoting greater absorption of nutrients and water.
\end{abstract}

Key words: plant growth promoting fungi, entomopathogenic fungi, arbuscular mycorrhizal, phytohormones.

\section{INTRODUCTION}

One of the great challenges facing society today is to plan and propose sustainable solutions to food production for an estimated population of 9 billion by 2050, according to the United Nations - UN projection (Searchinger et al. 2014). Despite the significant growth in food production to supply the population explosion in the last 50

Correspondence to: Lucas Carvalho Basilio Azevedo

E-mail: lucasazevedo@ufu.br years (FAOSTAT, http://www.fao.org/faostat/ en/\#data) (Pingali 2012), new methods of food production must be proposed (Dubey et al. 2016). The alternatives for improving production are the increase in cultivated areas or the increase in productivity (per unit of area), with investments in crop management (Larriba et al. 2015), use of pesticides and fertilizers, genetic improvement (Ahmad et al. 2012, Mannion and Morse 2012), use of biofertilizers or plant growth promoters. However, higher agricultural productions based 
on the significantly increasing use of chemicals cause environmental damage (Chapin et al. 2000, Parmesan and Yohe 2003).

In order to establish a sustainable agriculture, which will reduce the impacts caused to the environment, the use of microorganisms that promote plant growth has become an option (Berg 2009, Martínez-Medina et al. 2014). An example is the use of fungi as agents of biological control of pests and diseases, which can contribute to decrease pesticide use (Gerhardson 2002, Pineda et al. 2013, Zelicourt et al. 2013). In addition to the environmental impact, there is the economic issue: billions of dollars are lost annually due to the action of parasitic nematodes, pests, and fungi in various crops (Abad et al. 2008, Wesemael et al. 2010).

Besides infecting insects, nematodes, and microorganisms, some fungi also colonize plant tissues and may bring other benefits to the plant: they have been named as plant growth promoting fungi (PGPF) (Barelli et al. 2016, Ownley et al. 2010, Sasan and Bidochka 2012, Vega 2008). On the other hand, these endophytic fungi benefit from this association, which improves their $\mathrm{N}$ nutrition and enhance acquisition of photosynthates, in a probable relationship of metabolic exchange not fully understood. Mechanisms of plant growth promotion may be specific to each isolate fungalplant interaction, but may involve pest and disease control, phytohormone production, complexation and unavailability of toxic chemical species, interaction with beneficial microorganisms, and nutrient solubilization (Jung et al. 2012, Liao et al. 2014a, Oggerin et al. 2013).

For fungi of the genus Trichoderma, the main mechanisms proposed to explain growth in size and increase of plant resistance to diseases are the production of the phytohormones auxin, ethylene, and abscisic acid (Linkies et al. 2009, Martínez-Medina et al. 2014, Mok and Mok 2001, Raghavendra et al. 2010, Simon and Petrasek 2011). These phytohormones have a role in plant development and plant adaptation to stress conditions (Han et al. 2015, Zhang et al. 2011).

The entomopathogenic and endophytic fungus Purpureocillium lilacinum produces extracellular polymeric substances with active interfacial sites and can adsorb and complex metal ions, inducing nucleation and precipitation of minerals (Oggerin et al. 2013). This process protects plants from the stress generated by toxic metals (Mishra et al. 2017). This fungus also produces the phytohormone indoleacetic acid (the auxin IAA) and has several antifungal activities such as the production of ammonia and hydrolytic enzymes capable of degrading the cell walls of phytopathogenic fungi (Cavello et al. 2015).

The PGPF Pochonia chlamydosporia, in addition to fighting phytopathogenic nematodes (Carneiro et al. 2011, Dias-Arieira et al. 2011, Escudero and Lopez-Llorca 2012), has also been reported as growth promoting fungus of some crops, including lettuce (Dias-Arieira et al. 2011) and tomato (Escudero and Lopez-Llorca 2012).

Anumber of studies has reported the expression of plant genes related to biosynthesis and transport of plant growth and defense hormones in response to the endophytic colonization by these fungi (Bari and Jones 2009, Jung et al. 2012, Larriba et al. 2015, Maciá-Vicente et al. 2009b, Ozalvo et al. 2014). There is strong evidence that part of these phytohormone-related effects results in increased root growth. For example, the regulation of genes for auxin biosynthesis increased the root production in barley colonized by Pochonia chlamydosporia (Maciá-Vicente et al. 2009a).

Besides regulating the plant defense system and root growth, the effect of PGPF on phytohormone biosynthesis, especially jasmonic acid (JA) and abscisic acid (ABA), may stimulate symbiosis between plants and soil microorganisms such as the arbuscular mycorrhizal colonization of plants (Ballaré 2011, Conrath et al. 2006, Contreras- 
Cornejo et al. 2011, Jung et al. 2012, León-Morcillo et al. 2012, Martínez-Medina et al. 2011).

Therefore, these possible PGPF mechanisms in plant physiology and soil biology result in the promotion of root growth, shoot growth, and agricultural productivity (Chowdappa et al. 2013, Liao et al. 2014b, Jaber and Enkerli 2016, Martínez-Medina et al. 2014). However, studies have evaluated the use of one isolate or the consortium of two isolates of PGPF. Thus, to the best of our knowledge, no report has been found so far on the use of the consortium with the five fungal isolates described above. In this context, this study aimed to evaluate the effect of the combined application of the five fungal isolates, i.e., Beauveria bassiana, Metarhizium anisopliae, Pochonia chlamydosporia, Purpureocillium lilacinum, and Trichoderma asperella, on the growth, plant nutrition, and arbuscular mycorrhizal colonization in sugarcane, corn, and soybean.

\section{MATERIALS AND METHODS}

\section{GREENHOUSE ASSAYS}

Three assays with the crops sugarcane (variety RB93-7570), corn (variety AG 1051), and soybean (variety 7200 I Pro) were carried out in pots. Each crop received two treatments: (1) control without inoculation and (2) inoculation with five fungal isolates with potential to mediate plant growth: Beauveria bassiana, Metarhizium anisopliae, Pochonia chlamydosporia, Purpureocillium lilacinum, and Trichoderma asperellum.

For corn and soybean, 9 seeds were sown per pot containing $10 \mathrm{dm}^{3}$ of soil. Plants were thinned to two plants per pot when they reached the first pair of expanded leaves.

For sugarcane, 3 stem cuttings were planted per pot containing $50 \mathrm{dm}^{3}$ of soil.

The soil used in the experiment was collected from an area of a Rhodic Ferralsol (World Reference Base, http://www.fao.org/soils-portal/en/) (Table I), located in the Cerrado biome in the state of Minas Gerais, Brazil (18 $57^{\prime} 34^{\prime \prime} \mathrm{S}$; 48 $\left.8^{\circ} 12^{\prime} 05^{\prime \prime} \mathrm{W}\right)$, in November/2016. Before harvest, this soil was used for cultivating annual crops (corn in the summer 2015/2016 and sorghum in the winter 2016). The soil was fertilized for the assay, according to the recommendations for the crops (Table II).

The plots for corn and soybean were set up in duplicate to analyze development at flowering time and determine soil fertility and leaf and grain nutrition at the maturation time.

\section{PREPARATION OF THE FUNGAL CONSORTIUM INOCULUM}

Each isolate of the fungi Beauveria bassiana, Metarhizium anisopliae, Pochonia chlamydosporia, Purpureocillium lilacinum, and Trichoderma asperella was provided as inoculum in flask containing culture medium by the company BIOSAG - Comércio e Serviços Agrícolas Ltda.

The culture medium of each isolate was mixed with $500 \mathrm{~mL}$ of distilled water in a blender. The spores were counted in Neubauer's chamber and the five suspensions of fungal isolates were pooled, resulting in a final volume of $2.5 \mathrm{~L}$. This was the suspension used for seed and shoot application. The suspension contained, on average, $1.1 \times 10^{7} \mathrm{~mL}^{-1}$ of B. bassiana, $1.2 \times 10^{7} \mathrm{~mL}^{-1}$ of $M$. anisopliae, $0.3 \times$ $10^{7} \mathrm{~mL}^{-1}$ of $P$. chlamydosporia, $0.06 \times 10^{7} \mathrm{~mL}^{-1}$ of P. lilacinum, and $1.5 \times 10^{7} \mathrm{~mL}^{-1}$ of $T$. asperella.

\section{INOCULATING THE SEEDS}

Each 100 grams of seed was inoculated with 10 $\mathrm{mL}$ of the suspension containing the five fungal isolates. The mixture was homogenized in beaker using a glass rod.

\section{INOCULATING THE SHOOTS}

For leaf application, the $2.5 \mathrm{~L}$ of spore suspension (with the five fungal isolates) was diluted 1: 100 with distilled water $(990 \mathrm{ml}$ of distilled water and 10 
TABLE I

Initial fertility of the soil used as substrate in the assays with corn, soybean, and sugarcane.

\begin{tabular}{|c|c|c|c|c|c|c|c|}
\hline \multirow[t]{2}{*}{ pH } & O.C & $\mathrm{Ca}$ & Mg & $\mathbf{K}$ & Al & $\mathbf{H}+\mathbf{A l}$ & CTC \\
\hline & dag $k^{-1}$ & \multicolumn{6}{|c|}{$\mathrm{cmol}_{\mathrm{c}} \mathrm{kg}^{-1}$ soil } \\
\hline 5.8 & 2.2 & 3 & 0.9 & 0.2 & 0.1 & 4.2 & 8.3 \\
\hline
\end{tabular}

TABLE II

Amount of nutrients supplied to each pot in the assays with corn, soybean and sugarcane.

\begin{tabular}{ccccccc}
\hline Culture/Nutrient & $\mathbf{N}$ & $\mathbf{Z n}$ & $\mathbf{C u}$ & $\mathbf{M n}$ & $\mathbf{B}$ & $\mathbf{P}$ \\
\hline \multirow{7}{*}{ Soybean } & - & 2.0 & 0.25 & 1.25 & 0.25 \\
Corn & $25.0^{1}$ & - & - & - & - & 70.0 \\
Sugarcane & 30.0 & - & - & - & - & - \\
\hline
\end{tabular}

${ }^{1}$ - Divided in two, at 45 days and 90 days after plant emergence.

$\mathrm{mL}$ of the spore suspension). Two leaf applications were performed with a manual sprayer: for soybean and corn, at the phenological stage V3 (3 leaves developed) and after 28 days of the first application; for sugarcane, at seven days after planting and 28 days after the first application. The volumes used for spraying were determined according to the size of the plants (Table III).

\section{PLANT GROWTH}

Growth of corn and soybean was analyzed at the time of flowering (all plants with at least one flower/ inflorescence) and sugarcane at 160 days after planting. In the three assays, the growth parameters were evaluated at flowering: fresh and dry mass of shoot and roots and arbuscular mycorrhizal colonization. Nodules were counted in the roots of soybean plants. Dry weight was determined by incubating the samples in a $60{ }^{\circ} \mathrm{C}$ oven for 72 hours and then weighing the material on analytical balance.

\section{SOIL FERTILITY AND LEAF AND GRAIN NUTRITION}

At 160 days after planting sugarcane and at grain maturation of soybean and corn, we carried out the
TABLE III

Amount of fungal suspension (Beauveria bassiana, Metarhizium anisopliae, Pochonia chalamydosporia, Purpureocillium lilacinum, and Trichoderma asperella) sprayed to the crops with a hand sprayer.

\begin{tabular}{ccc}
\hline \multirow{2}{*}{ Culture } & $\mathbf{1}^{\text {st }}$ Application & $\mathbf{2}^{\text {nd }}$ Application \\
\cline { 2 - 3 } & \multicolumn{3}{c}{ mL plant $^{-1}$} \\
\hline Soybean $^{\mathbf{1}}$ & 5.0 & 8.0 \\
Corn $^{1}$ & 8.0 & 10.0 \\
Sugarcane $^{\mathbf{2}}$ & 10.0 & 15.0 \\
\hline
\end{tabular}

The suspension contained, on average, $1.1 \times 10^{7} \mathrm{~mL}^{-1}$ of $B$. bassiana, $1.2 \times 10^{7} \mathrm{~mL}^{-1}$ of $M$. anisopliae, $0.3 \times 10^{7} \mathrm{~mL}^{-1}$ of $P$. chlamydosporia, $0.06 \times 10^{7} \mathrm{~mL}^{-1}$ of $P$. lilacinum, and $1.5 \times 10^{7}$ $\mathrm{mL}^{-1}$ of $T$. asperella.

${ }^{1}$ - first application at the phenological stage V3 (3 leaves developed) and the second application 28 days after the first application.

2 - first application seven days after planting and the second application 28 days after the first application.

analyses of soil fertility, corn and sugarcane leaf nutrition, yield and nutrition of soybean seeds, as well as soybean pod husks. The soil was analyzed for $\mathrm{pH}$, organic carbon, $\mathrm{H}+\mathrm{Al}, \mathrm{Al}$, total $\mathrm{N}, \mathrm{P}, \mathrm{K}$, $\mathrm{Ca}, \mathrm{Mg}, \mathrm{S}, \mathrm{Zn}, \mathrm{Mn}, \mathrm{Cu}, \mathrm{Fe}$, and $\mathrm{B}$ (Teixeira et al. 2017). Plant tissues were analyzed for $\mathrm{P}, \mathrm{K}, \mathrm{Ca}$, $\mathrm{Mg}, \mathrm{S}, \mathrm{Zn}, \mathrm{Mn}, \mathrm{Cu}, \mathrm{Fe}$, and B (Silva 2009).

\section{ARBUSCULAR MYCORRHIZAL COLONIZATION}

The fungal structures internal to the roots were stained by the method of Vierheilig et al. (1998). Roots were washed in tap water to remove soil, cut in $2 \mathrm{~cm}$ fragments in the upper, middle, and lower third of the root system, and placed in histological cassettes in duplicates. For root clarification, the cassettes were immersed in $10 \% \mathrm{KOH}$ for 16 hours. The solution was renewed and the cassettes were incubated at $60{ }^{\circ} \mathrm{C}$ for 10 minutes. The roots were rinsed and placed in $1 \% \mathrm{HCl}$ solution for acidification. Finally, the fungal structures were stained at $90{ }^{\circ} \mathrm{C}$ for 3 minutes with a solution of $5 \%$ commercial Parker ${ }^{\circledR}$ pen ink, 5\% acetic acid, and $10 \%$ lactoglycerol. The determination of root length percentage colonized by the arbuscular 
mycorrhizal fungi (AMF) was carried out using the grid-line intersect method proposed by Giovannetti and Mosse (1980), in a stereoscope microscope.

\section{STATISTICS}

The 3 assays were arranged in a completely randomized design, with or without inoculation with the Biosag conditioner and six replicates. In the annual crops, the replicates were duplicated to allow analysis of plant development at flowering and plant nutrition after maturation. The occurrence of outliers were tested by the ACTION 2.9 program. After this first step, homogeneity of the treatment variances (Levene test, $\mathrm{p}>0.05$ ) and normality (Anderson - Darling test, $\mathrm{p}>0.05$ ) were tested. The means of the parametric variables were tested by analysis of variance (Levene test) and Tukey's test ( $p<0.05$ ), using the IBM SPSS Statistics program. The means of the non-parametric variables were tested by the Kruskal-Wallis test $(p<0.05)$, using the IBM SPSS Statistics program.

\section{RESULTS}

\section{PLANT GROWTH}

The inoculation with the fungal consortium showed a positive response in at least one of the plant growth parameters for soybean and corn (Table IV). Inoculation of soybean with fungal isolates significantly increased root dry mass by $89.32 \%$ and fresh roots mass by $43.71 \%$ compared with the uninoculated treatment (Table IV, $\mathrm{p}<0.05$ ). In corn, there was a significant increase in the fresh root mass by $53.39 \%$ in the inoculated treatment.

Soybean yield and pod husk mass showed no difference between treatments (Table V).

\section{ARBUSCULAR MYCORRHIZAL COLONIZATION}

Colonization by arbuscular mycorrhizal fungi ranged from $45 \%$ to $73 \%$ of root length (Figure 1). The colonization rate of the inoculated treatment compared with the uninoculated treatment was $20 \%$ higher for soybean and $28 \%$ higher for sugarcane $(\mathrm{p}<0.05)$. Corn roots showed no differences in the root length colonized by AMF between the two treatments.

\section{PLANT TISSUE ANALYSIS}

Most nutrient contents in plant tissue were not influenced by the treatments (Table VI). The two exceptions were boron in soybean and copper in corn, always with lower values in the inoculated treatment.

\section{SOIL FERTILITY}

The fungal inoculum and plant growth caused no changes in soil fertility; the only exception was the higher sulfur content in the uninoculated soybean treatment (Table VII).

\section{DISCUSSION}

Plant growth promoting fungi can influence plant growth in several ways (Carollo et al. 2010, Gibson et al. 2014, Liao et al. 2014b, Sasan and Bidocha 2012). A very common effect on plant development is the increased root growth (Jaber and Enkerli 2016, Maciá-Vicente et al. 2009b). Therefore, it is likely that the increase in the root mass of soybean and corn found in this study in inoculated plants is due to the stimulus of auxin production by the fungi and the ability of these microorganisms to induce plants to synthesize phytohormones (MartinezMedina et al.2014). Fungi of the genus Metarhizium (Liao et al. 2017), Purpureocillium (Cavello et al. 2015), Trichoderma (Contreras-Cornejo et al. 2009), Beauveria (Pedras and Montaut 2003), and Pochonia (Zavala-Gonzalez et al. 2015) have been reported as auxin producers. In addition, in barley, the fungus Pochonia chlamydosporia promotes root growth by regulating genes related to biosynthesis of auxins, which are involved in root growth (Maciá-Vicente et al. 2009b). In another experiment, Vicia faba seeds were treated 


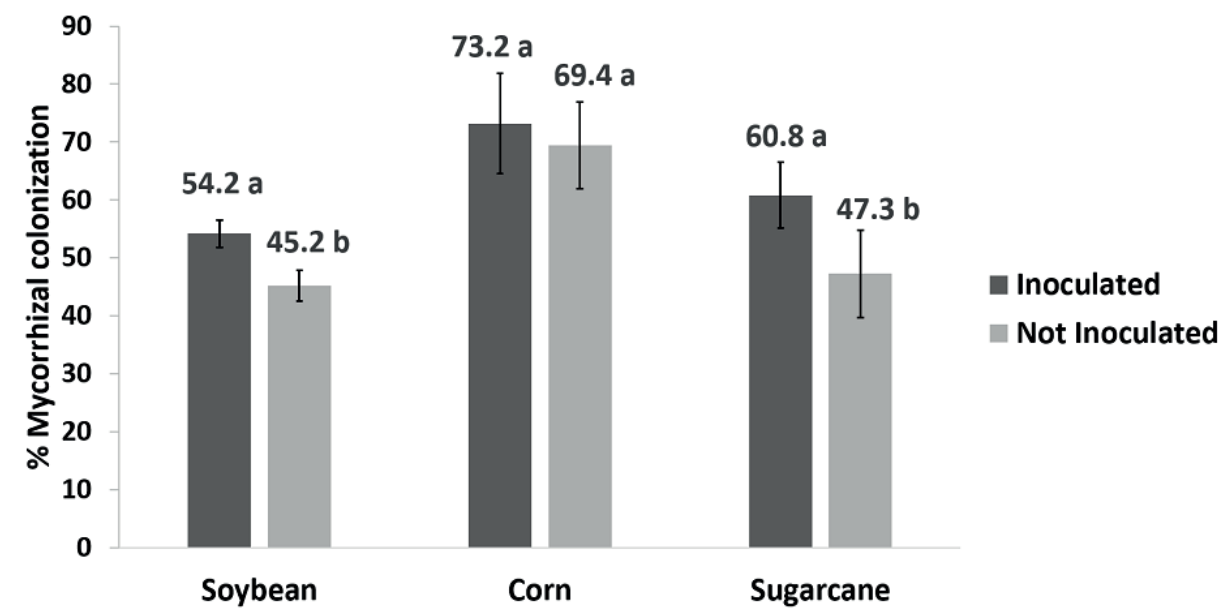

Figure 1 - Mycorrhizal colonization as percentage in soybean, sugarcane, and corn inoculated and uninoculated with the fungi Beauveria bassiana, Metarhizium anisopliae, Pochonia chalamydosporia, Purpureocillium lilacinum, and Trichoderma asperella.

TABLE IV

Growth variables of soybean, corn, and sugarcane inoculated and uninoculated with the fungal solution composed of the fungi Beauveria bassiana, Metarhizium anisopliae, Pochonia chalamydosporia, Purpureocillium lilacinum, and Trichoderma asperella.

\begin{tabular}{|c|c|c|c|c|}
\hline Variables & Treatment & Soybean & Corn & Sugarcane \\
\hline \multirow[t]{2}{*}{$\mathrm{SFM}\left(\mathrm{g} \operatorname{pot}^{-1}\right)$} & Inoculated & $53.44(6.62) \mathrm{a}$ & $199.76(25.26) \mathrm{a}$ & $1481.17(354.82)$ \\
\hline & Not Inoculated & $49.22(14.41) \mathrm{a}$ & $185.88(20.03) \mathrm{a}$ & $1418.24(199.43) \mathrm{a}$ \\
\hline \multirow[t]{2}{*}{$\operatorname{RFM}\left(\mathrm{g} \operatorname{pot}^{-1}\right)$} & Inoculated & $26.43(8.81) a$ & $213.69(65.20) \mathrm{a}$ & $1274.17(131.54)$ \\
\hline & Not Inoculated & $18.39(6.81) b$ & $139.31(30.55) b$ & $1205.60(196.79)$ \\
\hline \multirow[t]{2}{*}{$\mathrm{NFM}\left(\mathrm{g} \mathrm{pot}^{-1}\right)$} & Inoculated & $3.67(0.26) \mathrm{a}$ & - & - \\
\hline & Not Inoculated & $2.76(1.49) \mathrm{a}$ & - & - \\
\hline \multirow[t]{2}{*}{$\mathrm{SDM}\left(\mathrm{g} \mathrm{pot}^{-1}\right)$} & Inoculated & $11.66(3.47) \mathrm{a}$ & $101.21(32.21) \mathrm{a}$ & $451.03(93.55) \mathrm{a}$ \\
\hline & Not Inoculated & $11.51(2.88) \mathrm{a}$ & $124.04(48.43) \mathrm{a}$ & $417.70(76.63) \mathrm{a}$ \\
\hline \multirow[t]{2}{*}{$\mathrm{RDM}\left(\mathrm{g} \operatorname{pot}^{-1}\right)$} & Inoculated & $3.90(0.20) \mathrm{a}$ & $127.42(50.44) \mathrm{a}$ & $135.80(33.64) \mathrm{a}$ \\
\hline & Not Inoculated & $2.06(0.90) b$ & $83.43(6.75) \mathrm{a}$ & $146.52(17.79) \mathrm{a}$ \\
\hline \multirow[t]{2}{*}{ NDM (mg pot $\left.{ }^{-1}\right)$} & Inoculated & $477.78(78.92) \mathrm{a}$ & - & - \\
\hline & Not Inoculated & $354.08(127.07) \mathrm{a}$ & - & - \\
\hline \multirow[t]{2}{*}{ Nodules pot ${ }^{-1}$} & Inoculated & $208.20(16.30) \mathrm{a}$ & - & - \\
\hline & Not Inoculated & $211.50(81.13) \mathrm{a}$ & - & - \\
\hline
\end{tabular}

Means (standard deviation) $(n=6)$ of variables of plants grown in greenhouse followed by different small letters (in bold) are significantly different between inoculated and noninoculated treatments $(\mathrm{p}<0.05$, Tukey's test for parametric variables and Kruskal Wallis for non-parametric variables). SFM: Shoot Fresh Mass; RFM: Root Fresh Mass; NFM: Nodule Fresh Mass; SDM: Shoot Dry Mass; RDM: Root Dry Mass; NDM: Nodule Dry Mass. 
TABLE V

Soybean grain production of plants inoculated or uninoculated with the fungal solution composed of the fungi Beauveria bassiana, Metarhizium anisopliae, Pochonia chalamydosporia, Purpureocillium lilacinum, and Trichoderma asperella.

\begin{tabular}{ccc}
\hline Variables & Treatment & Soybean \\
\hline Weight of grains $\left(\mathrm{g} \mathrm{pot}^{-1}\right)$ & Inoculated & $14.41(6.21) \mathrm{a}$ \\
& Not Inoculated & $14.20(4.67) \mathrm{a}$ \\
Weight Bark $\left(\mathrm{g} \mathrm{pot}^{-1}\right)$ & Inoculated & $8.88(1.79) \mathrm{a}$ \\
& Not Inoculated & $7.37(1.96) \mathrm{a}$ \\
\hline
\end{tabular}

Means (standard deviation) $(n=6)$ of seed yield of soybean grown in the greenhouse followed by the same small letters indicate no difference between the inoculated and uninoculated treatments ( $p<0.05$, Tukey's test for parametric variables and Kruskal Wallis for non-parametric variables).

with a concentration of $10^{7}$ conidia $\mathrm{mL}^{-1}$ of PGPF Metarhizium brunneum and Beauveria bassiana, resulting in a significant increase in seedlings, plant height, and root weight (Jaber and Enkerli 2016), which was possibly explained by the production of auxins by fungi of the genus Metarhizium (Liao et al. 2014b).

The significant differences in the percentages of mycorrhizal colonization in soybean and sugarcane (Figure 1) can be explained by the production of jasmonic acid (AJ), salicylic acid (SA), and abscisic acid (ABA) by PGPF. JA, SA, and ABA were found in plants colonized by the fungus Trichoderma (Contreras-Cornejo et al. 2011, Martínez-Medina et al. 2011). At the same time that these regulators are related to increased plant tolerance to stress conditions, they also play a role in the regulation of arbuscular mycorrhizal symbiosis (Ballaré 2011, Etemadi et al. 2014, Foo et al. 2013, Fracetto et al. 2013, Hause et al. 2007, León- Morcillo et al. 2012, Tejeda- Sartorius et al. 2008).

An experiment comparing tomatoes genetically modified to suppress ABA synthesis with unmodified plants showed that the intensity of root colonization by Arbuscular Mycorrhizal Fungi (AMF) and arbuscular abundance were reduced drastically (Herrena-Medina et al. 2007).
One possible explanation for this phenomenon is that ABA negatively affects ethylene production, which has been shown to negatively affect AMF colonization in roots (Fracetto et al. 2013, Geil et al. 2001).

Furthermore, in Medicago truncatula genetically modified to reduce synthesis of JA, there was a reduction in the length of intraradicular hyphae and the number of arbuscules (Isayenkov et al. 2005). Among the supposed mechanisms of JA that collaborate with the symbiosis between AMF is the induction of the flavonoid synthesis, which are signals for the stimulation of colonization and reorganization of the microtubular cytoskeleton after colonization of roots by AMF (Genre and Bonfante 1998, Harrison 1999, Hause et al. 2007, Matsuki et al. 1992).

On the other hand, SA negatively affected mycorrhizal colonization in pea roots, in which high levels of this hormone were associated with low MA association (Blilou et al. 1999). In a study with tobacco, the numbers of infection units and arbuscules were higher when SA production was reduced in comparison with plants that produced elevated levels of SA (Herrera-Medina et al. 2003). However, it is interesting that high SA levels delay the maximum degree of colonization, but do not affect the maximum capacity of root colonization, since at the end of the experiment, the results between the treatments were similar (HerreraMedina et al. 2003).

Therefore, because PGPF are related to regulators that stimulate (ABA and $\mathrm{JA}$ ) or reduce (SA) mycorrhizal colonization, it is probable that these fungi play a role in the adjustment to a phytohormone balance that eventually promotes mycorrhizal colonization (Ballaré 2011, Conrath et al. 2006, Contreras-Cornejo et al. 2011, Foo et al. 2013, Jung et al. 2012, León-Morcillo et al. 2012, Martínez-Medina et al. 2011, Martín- Rodriguez et al. 2015, Wasternack and Hause 2013). 
TABLE VI

Nutrient contents in leaf tissues of sugarcane and corn and in soybean grains in plants inoculated and uninoculated with the fungal solution composed of the fungi Beauveria bassiana, Metarhizium anisopliae, Pochonia chalamydosporia, Purpureocillium lilacinum, and Trichoderma asperella.

\begin{tabular}{|c|c|c|c|c|}
\hline Variable & Treatment & Soybean grains & Corn grains & Sugarcane tissue \\
\hline \multirow[t]{2}{*}{$\mathrm{N}\left(\mathrm{g} \mathrm{kg}^{-1}\right)$} & Inoculated & $56.00(3.60) \mathrm{a}$ & $4.48(0.38) \mathrm{a}$ & $4.90(0.00) \mathrm{a}$ \\
\hline & Not Inoculated & $58.38(0.80) \mathrm{a}$ & $4.08(1.28) \mathrm{a}$ & $4.32(1.36) \mathrm{a}$ \\
\hline \multirow[t]{2}{*}{$\mathrm{P}\left(\mathrm{g} \mathrm{kg}^{-1}\right)$} & Inoculated & $5.18(1.11) \mathrm{a}$ & $3.03(1.03) \mathrm{a}$ & $1.68(0.86) \mathrm{a}$ \\
\hline & Not Inoculated & $5.47(0.76) \mathrm{a}$ & $2.85(0.56) \mathrm{a}$ & $1.30(0.58) \mathrm{a}$ \\
\hline \multirow[t]{2}{*}{$\mathrm{K}\left(\mathrm{g} \mathrm{kg}^{-1}\right)$} & Inoculated & $21.33(0.82) \mathrm{a}$ & $13.50(0.71) \mathrm{a}$ & $11.33(2.40) \mathrm{a}$ \\
\hline & Not Inoculated & $21.08(0.66) \mathrm{a}$ & $13.08(0.86) \mathrm{a}$ & $11.75(2.02) \mathrm{a}$ \\
\hline \multirow[t]{2}{*}{$\mathrm{Ca}\left(\mathrm{g} \mathrm{kg}^{-1}\right)$} & Inoculated & $3.50(0.55) \mathrm{a}$ & $2.00(0.00) \mathrm{a}$ & $3.50(0.55) \mathrm{a}$ \\
\hline & Not Inoculated & $3.17(0.41) \mathrm{a}$ & $2.17(0.41) \mathrm{a}$ & $3.33(0.52) \mathrm{a}$ \\
\hline \multirow[t]{2}{*}{$\operatorname{Mg}\left(\mathrm{g} \mathrm{kg}^{-1}\right)$} & Inoculated & $1.83(0.41) \mathrm{a}$ & $1.00(0.00) \mathrm{a}$ & $1.00(0.00) \mathrm{a}$ \\
\hline & Not Inoculated & $1.67(0.52) \mathrm{a}$ & $1.00(0.00) \mathrm{a}$ & $1.00(0.00) \mathrm{a}$ \\
\hline \multirow[t]{2}{*}{$\mathrm{S}\left(\mathrm{g} \mathrm{kg}^{-1}\right)$} & Inoculated & $1.63(0.24) \mathrm{a}$ & $1.73(1.27) \mathrm{a}$ & $0.62(0.10) \mathrm{a}$ \\
\hline & Not Inoculated & $2.03(0.20) \mathrm{a}$ & 1.55 (1.19) a & $0.60(0.07) \mathrm{a}$ \\
\hline \multirow[t]{2}{*}{$\mathrm{B}\left(\mathrm{mg} \mathrm{kg}^{-1}\right)$} & Inoculated & $38.00(3.46) b$ & $11.83(1.94) \mathrm{a}$ & $10.20(2.95) \mathrm{a}$ \\
\hline & Not Inoculated & $44.17(7.25) \mathrm{a}$ & $13.60(1.67) \mathrm{a}$ & $11.33(1.63) \mathrm{a}$ \\
\hline \multirow[t]{2}{*}{$\mathrm{Cu}\left(\mathrm{mg} \mathrm{kg}^{-1}\right)$} & Inoculated & $13.33(1.21) \mathrm{a}$ & $5.67(0.82) b$ & $7.50(0.84) \mathrm{a}$ \\
\hline & Not Inoculated & $13.80(1.64) \mathrm{a}$ & $6.33(0.82) \mathrm{a}$ & $7.17(1.17) \mathrm{a}$ \\
\hline \multirow[t]{2}{*}{$\mathrm{Fe}\left(\mathrm{mg} \mathrm{kg}^{-1}\right)$} & Inoculated & $94.67(30.65) \mathrm{a}$ & $221.67(78.23) \mathrm{a}$ & $305.67(167.52) \mathrm{a}$ \\
\hline & Not Inoculated & $60.50(46.89) \mathrm{a}$ & $141.33(30.17) \mathrm{a}$ & $271.80(103.54) \mathrm{a}$ \\
\hline \multirow[t]{2}{*}{$\operatorname{Mn}\left(\mathrm{mg} \mathrm{kg}^{-1}\right)$} & Inoculated & $30.60(2.41) \mathrm{a}$ & $34.67(6.38) \mathrm{a}$ & $90.00(9.97) \mathrm{a}$ \\
\hline & Not Inoculated & $33.00(3.63) \mathrm{a}$ & $42.50(10.48) \mathrm{a}$ & $103.20(5.76) \mathrm{a}$ \\
\hline \multirow[t]{2}{*}{$\mathrm{Zn}\left(\mathrm{mg} \mathrm{kg}^{-1}\right)$} & Inoculated & $51.00(5.51) \mathrm{a}$ & $22.00(4.94) \mathrm{a}$ & $10.17(2.14) \mathrm{a}$ \\
\hline & Not Inoculated & $49.50(4.04) \mathrm{a}$ & $17.50(1.52) \mathrm{a}$ & $10.17(2.71) \mathrm{a}$ \\
\hline
\end{tabular}

Means (standard deviation) $(n=6)$ of nutrient contents in leaf tissues (corn and sugarcane) and in soybean seeds of plants grown in greenhouse followed by different small letters (in bold) are significantly different between inoculated and uninoculated treatments ( $\mathrm{p}<0.05$, Tukey test for parametric variables and Kruskal Wallis for non-parametric variables).

Although PGPF have the ability to solubilize/ chelate phosphorus, manganese, and zinc in soil (Altomare et al. 1999, Bareen et al. 2012), there were no changes in the concentrations of these nutrients in the soil or plant tissue. In this context, to the best of our knowledge, no report attesting to the influence of the five fungi tested here on soil fertility and nutrient contents in plant tissues has been published so far.

The only variable of soil fertility showing statistical difference between the treatments was sulfate in soybean, which was lower in the inoculated treatment. A possible reason for this difference between the treatments is the greater amount of sulfate removed from the soil by the plants. It has been shown that onion growing in low P soil, but inoculated with mycorrhiza, absorb more sulfate compared to non-mycorrhizal plants (Rhodes and Gerdemann 1978). The greater mycorrhizal colonization of soybean inoculated with PGPF may have favored higher sulphate uptake, reducing soil levels.

In conclusion, the five PGPF conditions root growth in soybean and corn and arbuscular mycorrhizal colonization in sugarcane. The 
TABLE VII

Fertility attributes of soil under soybean, corn, and sugarcane inoculated or uninoculated with the fungal solution composed of the fungi Beauveria bassiana, Metarhizium anisopliae., Pochonia chalamydosporia, Purpureocillium lilacinum, and Trichoderma asperella.

\begin{tabular}{|c|c|c|c|c|}
\hline Variable & Treatment & Soybean & Corn & Sugarcane \\
\hline \multirow[t]{2}{*}{$\mathrm{pH}$} & Inoculated & $5.60(0.00) \mathrm{a}$ & $5.67(0.12) \mathrm{a}$ & $5.52(0.12) \mathrm{a}$ \\
\hline & Not Inoculated & $5.44(0.05) \mathrm{a}$ & $5.73(0.08) \mathrm{a}$ & $5.65(0.15) \mathrm{a}$ \\
\hline \multirow[t]{2}{*}{$\mathrm{P}\left(\mathrm{mg} \mathrm{kg}^{-1}\right)$} & Inoculated & $21.82(2.64) \mathrm{a}$ & $41.95(19.44) \mathrm{a}$ & $20.57(0.99) \mathrm{a}$ \\
\hline & Not Inoculated & $29.17(5.42) \mathrm{a}$ & $126.20(8.35) \mathrm{a}$ & $24.00(2.55) \mathrm{a}$ \\
\hline \multirow[t]{2}{*}{$\mathrm{S}-\mathrm{SO}_{4}\left(\mathrm{mg} \mathrm{kg}^{-1}\right)$} & Inoculated & $3.20(0.40) \mathrm{b}$ & $4.83(0.75) \mathrm{a}$ & $3.20(0.45) \mathrm{a}$ \\
\hline & Not Inoculated & $4.00(0.00) \mathrm{a}$ & $4.83(0.41) \mathrm{a}$ & $2.50(0.84) \mathrm{a}$ \\
\hline \multirow[t]{2}{*}{$\mathrm{K}\left(\mathrm{cmol}_{\mathrm{c}} \mathrm{kg}^{-1}\right)$} & Inoculated & $0.07(0.01) \mathrm{a}$ & $0.37(0.07) \mathrm{a}$ & $0.06(0.01) \mathrm{a}$ \\
\hline & Not Inoculated & $0.08(0.01) \mathrm{a}$ & $0.31(0.01) \mathrm{a}$ & $0.06(0.01) \mathrm{a}$ \\
\hline \multirow[t]{2}{*}{$\mathrm{Ca}\left(\mathrm{cmol}_{\mathrm{c}} \mathrm{kg}^{-1}\right)$} & Inoculated & $3.18(0.32) \mathrm{a}$ & $2.93(0.10) \mathrm{a}$ & $2.87(0.10) \mathrm{a}$ \\
\hline & Not Inoculated & $3.22(0.29) \mathrm{a}$ & $2.87(0.10) \mathrm{a}$ & $2.86(0.09) \mathrm{a}$ \\
\hline \multirow[t]{2}{*}{$\operatorname{Mg}\left(\mathrm{cmol}_{\mathrm{c}} \mathrm{kg}^{-1}\right)$} & Inoculated & $0.70(0.08) \mathrm{a}$ & $0.83(0.08) \mathrm{a}$ & $0.87(0.05) \mathrm{a}$ \\
\hline & Not Inoculated & $0.68(0.08) \mathrm{a}$ & $0.78(0.08) \mathrm{a}$ & $0.88(0.08) \mathrm{a}$ \\
\hline \multirow[t]{2}{*}{$\mathrm{H}+\mathrm{Al}\left(\mathrm{cmol}_{\mathrm{c}} \mathrm{kg}^{-1}\right)$} & Inoculated & $3.93(0.30) \mathrm{a}$ & $3.97(0.20) \mathrm{a}$ & $4.20(0.00) \mathrm{a}$ \\
\hline & Not Inoculated & $4.07(0.21) \mathrm{a}$ & $3.90(0.17) \mathrm{a}$ & $4.28(0.11) \mathrm{a}$ \\
\hline \multirow[t]{2}{*}{$\mathrm{CO}\left(\operatorname{dag} \mathrm{Kg}^{-1}\right)$} & Inoculated & $1.40(0.14) \mathrm{a}$ & $1.43(0.05) \mathrm{a}$ & $1.40(0.09) \mathrm{a}$ \\
\hline & Not Inoculated & $1.42(0.12) \mathrm{a}$ & $1.37(0.05) \mathrm{a}$ & $1.33(0.10) \mathrm{a}$ \\
\hline \multirow[t]{2}{*}{$\mathrm{B}\left(\mathrm{mg} \mathrm{kg}^{-1}\right)$} & Inoculated & $0.22(0.06) \mathrm{a}$ & $0.17(0.01) \mathrm{a}$ & $0.14(0.02) \mathrm{a}$ \\
\hline & Not Inoculated & $0.24(0.05) \mathrm{a}$ & $0.18(0.03) \mathrm{a}$ & $0.16(0.03) \mathrm{a}$ \\
\hline \multirow[t]{2}{*}{$\mathrm{Cu}\left(\mathrm{mg} \mathrm{kg}^{-1}\right)$} & Inoculated & $0.88(0.20) \mathrm{a}$ & $0.70(0.00) \mathrm{a}$ & $0.72(0.12) \mathrm{a}$ \\
\hline & Not Inoculated & $0.93(0.08) \mathrm{a}$ & $0.72(0.04) \mathrm{a}$ & $0.72(0.04) \mathrm{a}$ \\
\hline \multirow[t]{2}{*}{$\mathrm{Fe}\left(\mathrm{mg} \mathrm{kg}^{-1}\right)$} & Inoculated & $36.17(10.81) \mathrm{a}$ & $30.00(7.85) \mathrm{a}$ & $26.00(3.08) \mathrm{a}$ \\
\hline & Not Inoculated & $26.83(2.99) \mathrm{a}$ & $29.17(7.22) \mathrm{a}$ & $29.33(2.58) \mathrm{a}$ \\
\hline \multirow[t]{2}{*}{$\operatorname{Mn}\left(\mathrm{mg} \mathrm{kg}^{-1}\right)$} & Inoculated & $1.48(0.22) \mathrm{a}$ & $1.55(0.44) \mathrm{a}$ & $1.78(0.54) \mathrm{a}$ \\
\hline & Not Inoculated & $1.45(0.36) \mathrm{a}$ & $1.57(0.23) \mathrm{a}$ & $1.68(0.49) \mathrm{a}$ \\
\hline \multirow[t]{2}{*}{$\mathrm{Zn}\left(\mathrm{mg} \mathrm{kg}^{-1}\right)$} & Inoculated & $3.62(1.32) \mathrm{a}$ & $1.12(0.08) \mathrm{a}$ & $1.18(0.13) \mathrm{a}$ \\
\hline & Not Inoculated & $3.18(0.56) \mathrm{a}$ & $1.08(0.04) \mathrm{a}$ & $1.13(0.05) \mathrm{a}$ \\
\hline
\end{tabular}

Means (standard deviation) $(\mathrm{n}=6)$ of nutrient contents in soils of pots with plants grown in greenhouse followed by different small letters (in bold) are significantly different between inoculated and uninoculated treatments $(\mathrm{p}<0.05$, Tukey test for parametric variables and Kruskal Wallis for non-parametric variables).

probable mechanisms involved are the production and regulation of plant phytohormones synthesis. As far as we know, no report has been found on the application of a consortium with the five endophytic fungi in study, nor an investigation showing the direct influence of inoculation of these microorganisms on the AMF colonization in the roots. Greater root development linked to increased mycorrhizal colonization may result in more efficient absorption of nutrients and water. These results also suggest indirect effects on the soil such as the improvement in structure, aeration, and rhizosphere stimulation, with consequences for nutrient cycling. Therefore, the effects observed here are important when seeking conservation strategies for land use by allowing reduction in fertilizer demand. 


\section{ACKNOWLEDGMENTS}

The authors thank the reviewers for their comments and suggestions for improving this manuscript. This study was funded by Biosag Comércio e Serviços Agrícolas LTDA. Mr. CP Faria received a scholarship from Biosag.

\section{REFERENCES}

ABAD P, GOUZY J, AURY JM, CASTAGNONE-SERENO P, DANCHIN EGJ, DELEURY E, PERFUS-BARBEOCH L, ANTHOUARD V, ARTIGUENAVE F AND BLOK VC. 2008. Genome sequence of the metazoan plant-parasitic nematode Meloidogyne incognita. Nat Biotechnol 26: 909915.

AHMAD P, ASHRAF M, YOUNIS M, HU X, KUMAR A, AKRAM NA AND AL-QURAINY F. 2012. Role of transgenic plants in agriculture and biopharming. Biotechnol Adv 30: 524-540.

ALTOMARE C, NORVELL WA, BJORKMAN T AND HARMAN GE. 1999. Solubilization of phosphates and micronutrients by the plant-growth-promoting and biocontrol fungus Trichoderma harzianum rifai 1295-22. Appl Environ Microbiol 65: 2926-2933.

BALLARÉ CL. 2011. Jasmonate-induced defenses: a tale of intelligence, collaborators and rascals. Trends Plant Sci 16: 249-257.

BAREEN F, SHAFIQ M AND JAMIL S. 2012. Role of plant growth regulators and a saprobic fungus in enhancement of metal phytoextraction potential and stress alleviation in pearl millet. J Hazard Mater 237-238: 186-193.

BARELLI L, MOONJELY S, BEHIE SW AND BIDOCKA MJ. 2016. Fungi with multifunctional lifestyles: endophytic insect pathogenic fungi. Plant Mol Biol 90: 657-664.

BARI R AND JONES JD. 2009. Role of plant hormones in plant defense responses. Plant Mol Biol 69: 473-488.

BERG G. 2009. Plant-microbe interactions promoting plant growth and health: perspectives for controlled use of microorganisms in agricultura. Appl Microbiol Biotechnol 84: 11-18.

BLILOU JA, OCAMPO JM AND GARCÍA-GARRIDO JM. 1999. Resistance of pea roots to endomycorrhizal fungus or Rhizobium correlates with enhanced levels of endogenous salicylic acid. J Exp Bot 50: 1663-1668.

CARNEIRO RMDG, HIDALGO-DÍAZ L, MARTINS I, SILVA KFAS, SOUSA MG AND TIGANO MS. 2011. Effect of nematophagous fungi on reproduction of Meloidogyne enterolobii on guava (Psidium guajava) plants. Nematology 13: 721-728.

CAROLLO CA, CALIL ALA, SCHIAVE LA, GUARATINI T, ROBERTS DW, LOPES NP AND BRAGA GU. 2010.
Fungal tyrosine betaine, a novel secondary metabolite from conidia of entomopathogenic Metarhizium spp. fungi. Fungal Biol 114: 473-480.

CAVELLO IA, CRESPO J M, GARCIA SS, ZAPIOLA JM, LUNA MF AND CAVALITTO SF. 2015. Plant growth promotion activity of keratinolytic fungi growing on a recalcitrant waste known as "Hair Waste". Biotechnol Res Int, $10 \mathrm{p}$.

CHAPIN FS ET AL. 2000. Consequences of changing biodiversity. Nature 405: 234-242.

CHOWDAPPA P, MOHAN KUMAR SP, LAKSHMI MJ AND UPRETI KK. 2013. Growth stimulation and induction of systemic resistance in tomato against early and late blight by Bacillus subtilis OTPB1 or Trichoderma harzianum OTPB3. Biol Control 6: 109-117.

CONRATH U ET AL. 2006. Priming: getting ready for battle. Mol Plant Microbe Interact 19: 1062-1071.

CONTRERAS-CORNEJO HA, MACÍAS-RODRÍGUEZ L, BELTRÁN-PEÑA E, HERRERA- ESTRELLA A AND LÓPEZ-BUCIO J. 2011. Trichoderma-induced plant immunity likely involves both hormonal- and camalexin dependent mechanisms in Arabidopsis thaliana and confers resistance against necrotrophic fungus Botrytis cinerea. Plant Signal Behav 6: 1554-1563.

CONTRERAS-CORNEJO HA, MACÍAS-RODRÍGUEZ L, CORTÉS-PENAGOS C AND LÓPEZ- BUCIO J. 2009. Trichoderma virens, a plant beneficial fungus, enhances biomass production and promotes lateral root growth through an auxin-dependent mechanism in Arabidopsis. Plant Physiol 149: 1579-1592.

DIAS-ARIEIRA CR, SANTANA SM, DE FREITAS LG, DA CUNHA TPL, BIELA F, PUERARI HH AND CHIAMOLERA FM. 2011. Efficiency of Pochonia chlamydosporia in Meloidogyne incognita control in lettuce crop (Lactuca sativa L.). J Food Agric Environ 9: 561-563.

DUBEY RK, TRIPATHI V, DUBEY PK, SINGH HB AND ABHILASH PC. 2016. Exploring rhizospheric interactions for agricultural sustainability: the need of integrative research on multi-trophic interactions. J Clean Prod 115: 362-365.

ESCUDERO N AND LOPEZ-LLORCA LV. 2012. Effects on plant growth and root-knot nematode infection of an endophytic GFP transformant of the nematophagous fungus Pochonia chlamydosporia. Symbiosis 57: 33-42.

ETEMADI M, GUTJAHR C, COUZIGOU JM, ZOUINE M, LAURESSERGUES D, TIMMERS A, AUDRAN C, BOUZAYEN M, BECARD G AND COMBIER JP. 2014. Auxin perception is required for arbuscule development in arbuscular mycorrhizal symbiosis. Plant Physiol 166: 281-292. 
FOO E, ROSS JJ, JONES WT AND REID JB. 2013. Plant hormones in arbuscular mycorrhizal symbioses: an emerging role for gibberellins. Ann Bot 111: 769-779.

FRACETTO GGM, PERES LEP, MEHDY MC AND LAMBAIS MR. 2013. Tomato ethylene mutants exhibit differences in arbuscular mycorrhiza development and levels of plant defense related transcripts. Symbiosis 60 : 155-167.

GEIL RD, PETERSON RL AND GUINEL FC. 2001. Morphological alterations of pea (Pisum sativum cv. Sparkle) arbuscular mycorrhizas as a result of exogenous ethylene treatment. Mycorrhiza 11: 137-143.

GENRE A AND BONFANTE P. 1998. Actin versus tubulin configuration in arbuscule-containing cells from mycorrhizal tobacco roots. New Phytol 140: 745-752.

GERHARDSON B. 2002. Biological substitutes for pesticides. Trends Biotechnol 20: 338-343.

GIBSON DM, DONZELLI BG, KRASNOFF SB AND KEYHANI NO. 2014. Discovering the secondary metabolite potential encoded within entomopathogenic fungi. Nat Prod Rep 31: 1287-1305.

GIOVANNETTI M AND MOSSE B. 1980. An evaluation of techniques for measuring vesicular arbuscular mycorrhizal infection in roots. New Phytol 84: 489-500.

HAN Y ET AL. 2015. 1-aminocyclopropane-1-carboxylate deaminase from Pseudomonas stutzeri a1501 facilitates the growth of rice in the presence of salt or heavy metals. $J$ Microbiol Biotechnol 25: 1119-1128.

HARRISON M. 1999. Molecular and cellular aspects of the arbuscular mycorrhizal symbiosis. Annu Rev Plant Physiol Plant Mol Biol 50: 361-389.

HAUSE B, MROSK C, ISAYENKOV S AND STRACK D. 2007. Jasmonates in arbuscular mycorrhizal interactions. Phytochemistry 8: 101-110.

HERRERA-MEDINA MJ, GAGNON H, PICHÉ Y, OCAMPO JA, GARCÍA-GARRIDO JM AND VIERHEILIG $\mathrm{H}$. 2003. Root colonization by arbuscular mycorrhizal fungi is affected by the salicylic acid content of the plant. Plant Science 164: 993-998.

HERRERA-MEDINA MJ, STEINKELLNER S, VIERHEILIG H, BOTE JAO AND GARCÍA-GARRIDO JM. 2007. Abscisic acid determines arbuscule development and functionality in the tomato arbuscular mycorrhiza. New Phytol 175: 554-564.

ISAYENKOV S, MROSK C, STENZEL I, STRACK D AND HAUSE B. 2005. Suppression of allene oxide cyclase in hairy roots of Medicago truncatula reduces jasmonate levels and the degree of mycorrhization with Glomus intraradices. Plant Physiol 139: 1401-1410.

JABER LR AND ENKERLI J. 2016. Effect of seed treatment duration on growth and colonization of Vicia faba by endophytic Beauveria bassiana and Metarhizium brunneum. Biol Control 103: 187-195.

JUNG SC, MARTÍNEZ-MEDINA A, LOPEZ-RAEZ JÁ AND POZO MJ. 2012. Mycorrhiza-induced resistance and priming of plant defenses. J Chem Ecol 38: 651-664.
LARRIBA E, JAIME MDLA, NISLOW C, MARTÍNNIETO J AND LOPEZ- LLORCA LV. 2015. Endophytic colonization of barley (Hordeum vulgare) roots by the nematophagous fungus Pochonia chlamydosporia reveals plant growth promotion and a general defense and stress transcriptomic response. Journal Plant Res 128: 665-678.

LEÓN-MORCILLO RJ, MARTÍN-RODRÍGUEZ AJ, VIERHEILIG H, OCAMPO JÁ AND GARCIÁGARRIDO JM. 2012. Late activation of the 9-oxylipin pathway during arbuscular mycorrhizal formation in tomato and its regulation by jasmonate signaling. J Exp Bot 63: 3545-3558.

LIAO X, LOVETT B, FANG W AND ST LEGER RJ. 2017. Metarhizium robertsii produces indole-3-acetic acid, which promotes root growth in Arabidopsis and enhances virulence to insects. Microbiology 163: 980-991.

LIAO X, LU H-L, FANG W AND ST. LEGER RJ. 2014a. Overexpression of a Metarhizium robertsii HSP25 gene increases thermotolerance and survival in soil. Appl Microbiol Biotechnol 98: 777-783.

LIAO X, O'BRIEN TR, FANG W AND LEGER RJS. 2014b. The plant beneficial effects of Metarhizium species correlate with their association with roots. Appl Microbiol Biotechnol 98: 7089-7096.

LINKIES A ET AL. 2009. Ethylene interacts with abscisic acid to regulate endosperm rupture during germination: a comparative approach using Lepidium sativum and Arabidopsis thaliana. Plant Cell 21: 3803-3822.

MACIÁ-VICENTE JG, JANSSON HB, TALBOT NJ AND LOPEZ-LLORCALV.2009a. Real-timePCR quantification and live-cell imaging of endophyticcolonization of barley (Hordeum vulgare) roots by Fusarium equiseti and Pochonia chlamydosporia. New Phytol 182: 213-228.

MACIÁ-VICENTE JG, ROSSO LC, CIANCIO A, JANSSON HB AND LOPEZ-LLORCA LV. 2009b. Colonisation of barley roots by endophytic Fusarium equiseti and Pochonia chlamydosporia: Effects on plant growth and disease. Ann Appl Biol 155: 391-401.

MANNION AM AND MORSE S. 2012. Biotechnology in agriculture: agronomic and environmental considerations and reflections based on 15 years of GM crops. Prog Phys Geog 36: 747-763.

MARTÍN-RODRÍGUEZ JA, MOLINERO-ROSALES N, TARKOWSKÁ D, RUÍZ- RIVERO O AND GARCÍAGARRIDO JM. 2015. Role of gibberellins during arbuscular mycorrhizal formation in tomato: new insights revealed by endogenous quantification and genetic analysis of their metabolism in mycorrhizal roots. Physiol Plantarum 154: 66-81.

MARTÍNEZ-MEDINA A, ALGUACIL MDM, PASCUAL JA AND VAN WESS SCM. 2014. Phytohormone profiles induced by Trichoderma isolates correspond with their biocontrol and plant growth-promoting activity on melon plants. Journal Chem Ecol 40: 804-815.

MARTÍNEZ-MEDINA A, ROLDÁN A, ALBACETE A AND PASCUAL JA. 2011. The interaction with arbuscular 
mycorrhizal fungi or Trichoderma harzianum alters the shoot hormonal profile in melon plants. Phytochem 72: 223-229.

MATSUKI T, TAZAKI H, FUJIMORI T AND HOGETSU T. 1992. The influences of jasmonic acid methyl ester on microtubules in potato cells and formation of potato tubers. Biosci Biotechnol Biochem 56: 1329-1330.

MISHRA J, SINGH R AND ARORA NK. 2017. Alleviation of heavy metal stress in plants and remediation of soil by rhizosphere microorganisms. Front Microbiol 8: 1706.

MOK DWS AND MOK MC. 2001. Cytokinin metabolism and action. Annu Rev Plant Physiol Plant Mol Biol 52: 89-118.

OGGERIN M, TORNOS F, RODRÍGUEZ N, DEL MORAL C, SÁNCHEZ-ROMÁN M AND AMILS R. 2013. Specific jarosite biomineralization by Purpureocillium lilacinum, an acidophilic fungi isolated from Río Tinto. Environ Microbiol 15: 2228-2237.

OWNLEY BH, GWINN KD AND VEGA FE. 2010. Endophytic fungal entomopathogens with activity against plant pathogens: ecology and evolution. Ecol Fungal Entomopathog 55: 113-128.

OZALVO R, CABRERA J, ESCOBAR C, CHRISTENSEN SA, BORREGO EJ, KOLOMIETS MV, CASTRESANA C, IBERKLEID I AND HOROWITZ SB. 2014. Two closely related members of Arabidopsis 13-lipoxygenases (13-LOXs), LOX3 and LOX4, reveal distinct functions in response to plant-parasitic nematode infection. Mol Plant Pathol 15: 319-332.

PARMESAN C AND YOHE G. 2003. A globally coherent fingerprint of climate change impacts across natural systems. Nature 421: 37-42.

PEDRAS MSC AND MONTAUT S. 2003. Probing crucial metabolic pathways in fungal pathogens of crucifers: biotransformation of indole-3-acetaldoxime, 4-hydroxyphenylacetaldoxime, and their metabolites. Bioor Med Chem 11: 3115-3120.

PINEDA A, DICKE M, PIETERS CMJ AND POZO MJ. 2013. Beneficial microbes in a changing environment: are they always helping plants to deal with insects. Funct Ecol 27: $374-586$.

PINGALI P. 2012. Green revolution: impacts, limits, and the path ahead. Proc Natl Acad Sci USA 109: 12302-12308.

RAGHAVENDRA AS, GONUGUNTA VK, CHRISTMANN A AND GRILL E. 2010. ABA perception and signalling. Trends Plant Sci 15: 395-401.

RHODES LH AND GERDEMANN JW. 1978. Hyphal translocation and uptake of sulfur by vesicular-arbuscular mycorrhizae of onion. Soil Biol Biochem 10: 355-360.

SASAN RK AND BIDOCHKA MJ. 2012. The insectpathogenic fungus Metarhizium robertsii (Clavicipitaceae) is also an endophyte that stimulates plant root development. Am J Bot 99: 101-107.

SCHÄFER P ET AL. 2009. Manipulation of plant innate immunity and gibberellin as factor of compatibility in the mutualistic association of barley roots with Piriformospora indica. Plant J 59: 461-474.
SEARCHINGER T ET AL. 2014. Creating a sustainable food future. A menu of solutions to sustainably feed more than 9 billion people by 2050. World Resources Report 20132014, 154 p.

SILVA FC. 2009. Manual de análises químicas de solos, plantas e fertilizantes. $2^{\text {nd }}$ ed., Brasília: Embrapa Informação Tecnológica, $627 \mathrm{p}$.

SIMON S AND PETRASEK J. 2011. Why plants need more than one type of auxin. Plant Sci 180: 454-460.

TEIXEIRA PC, DONAGEMMA GK, FONTANA A AND TEIXEIRA WG. 2017. Manual de Métodos de Análise de Solo, $3^{\text {rd }}$ ed., Brasília: Embrapa, 573 p.

TEJEDA-SARTORIUS M, DE LA VEGA MO AND DÉLANO-FRIER JP. 2008. Jasmonic acid influences mycorrhizal colonization in tomato plants by modifying the expression of genes involved in carbohydrate partitioning. Physiol Plant 133: 339-353.

VEGA FE. 2008. Insect pathology and fungal endophytes. J Invertebr Pathol 98: 277-279.

VIERHEILIG H, COUGHLAN AP, WYSS U AND PICHÉ Y. 1998. Ink and vinegar, a simple staining technique for arbuscular mycorrhizal fungi. Appl Environ Microbiol 64: 5004-5007.

WALLER F, MUKHERJEE K, DESHMUKH SD, ACHATZ B, SHARMA M, SCHÄFER P AND KOGEL KH. 2008. Systemic and local modulation of plant responses by Piriformospora indica and related Sebacinales species. J Plant Physiol 165: 60-70.

WASTERNACK C AND HAUSE B. 2013. Jasmonates: biosynthesis, perception, signal transduction and action in plant stress response, growth and development. An update to the 2007 review in Annals of Botany Ann Bot 111: 1021-1058.

WESEMAEL WML, VIAENE N AND MOENS M. 2010. Root-knot nematodes (Meloidogyne spp.) in Europe. Nematology 13: 3-16.

ZAVALA-GONZALES EA, ESCUDERO N, LOPEZ-MOYA F, ARANDA-MARTINEZ A, EXPOSITO, A, RICAÑORODRÍGUEZ J, NARANJO-ORTIZ MA, RAMÍREZLEPE M AND LOPEZ-LLORCA LV. 2015. Some isolates of the nematophagous fungus Pochonia chlamydosporia promote root growth and reduce flowering time of tomato. Ann Appl Biol 166: 472-483.

ZELICOURT AD, AL-YOUSIF M AND HIRT H. 2013. Rhizosphere microbes as essential partners for plant stress tolerance. Mol Plant 6: 242-245.

ZHANG X, XIA H, LI Z, ZHUANG P AND GAO B. 2011. Identification of a new potential Cd-hyperaccumulator Solanum photeinocarpum by soil seed bank-metal concentration gradient method. J Hazard Mater 189: 414419. 